\title{
90. Genetic Differences between Swamp and River Buffaloes in the Electrophoretic Variations of Albumin and Transferrin
}

\author{
By Takashi Amano,*) Takao Namikawa, ${ }^{* *}$ and Shozo SUzUKI*) \\ (Communicated by Shoei Iseki, M. J. A., Sept. 12, 1980)
}

Domestic water buffaloes (Bubalus bubalis) are broadly classified into two different types, Swamp and River buffaloes. The name "Swamp buffalo" has been used for all the native water buffaloes in Southeast Asia. On the other hand, the name "River buffalo" has been used for all of the types distributed in India and farther West.11) Swamp buffaloes are much closer to the wild type than River buffaloes morphologically, and they are used mainly as draft animals and for meat. The River buffalo has been selected to improve the breeds with a higher milk yield. ${ }^{13)}$ In comparing the cytogenetic difference between these two types of water buffaloes, Fischer and Ulbrih $^{5)}$ reported that the diploid chromosome number of the Swamp buffaloes was 48, whereas that of Murrah, one of typical River buffalo breed, was 50, and their crossbred was 49 .

Researches ${ }^{1-4), 10)}$ have also been conducted on the blood protein polymorphisms of Swamp buffaloes in Southeast Asia by using the electrophoretic technique. However, the biochemical genetic differences between the two different types of water buffaloes have not yet been compared. In this paper, the electrophoretic variations of the albumin and transferrin in the Swamp, River, and their crossbred buffalo populations will be discussed.

Materials and methods. Blood samples were collected from 146 Swamp, 36 River, and 13 crossbred buffaloes. Among them, 60 Swamp and 16 River (Murrah group) buffaloes were raised by farmers in 5 States of Malaysia in 1975, and 86 Swamp buffaloes were sampled in two slaughter-houses in Manila and on two other Islands, 20 River buffaloes (Murrah group) and 13 of the crossbreds were at the Central Luzon State University in the Philippines in 1971 and 1979.

Most of the blood samples were taken with small plastic bottles or vacuum test tubes containing heparin powder. Then they were separated into cells and plasma by centrifugation for electrophoresis.

*) Department of Zootechnical Science, Tokyo University of Agriculture, 1-1-1 Sakuragaoka, Setagaya-ku, Tokyo 156.

**) Department of Animal Genetics, Faculty of Agriculture, Nagoya University, Nagoya-shi 464 . 
[Vol. $56(\mathrm{~B})$,

The plasma was diluted 3 times with distilled water for albumin analysis.

The albumin types were analyzed by the starch-gel electrophoretic technique as described by Kristjansson" ${ }^{9}$ with a small modification, namely that the gel buffer was adjusted to $\mathrm{pH}$ 5.7. The transferrin types were also analyzed by the starch-gel electrophoretic method described by Gahne. ${ }^{6)}$

Results and discussion. The albumin phenotypes are shown in Fig. 1, whereas the observed and expected numbers and gene frequencies in the Swamp, River, and crossbred buffalo populations are shown in Table I. The results for the River buffaloes corresponded with those of other researchers. ${ }^{8), 12), 14)}$ They described three albumin phenotypes ( $\mathrm{Alb} \mathrm{A}, \mathrm{AB}, \mathrm{B}$ or F, FS, S) in Bulgarian, Indian (Mur$\mathrm{rah}$ ), and Italian water buffaloes, and suggested that the variation was controlled by two codominant autosomal alleles named $\mathrm{Alb}^{\mathrm{A}}$ and $\mathrm{Alb}^{\mathrm{B}}$ or $\mathrm{Alb}^{\mathrm{F}}$ and $\mathrm{Alb}^{\mathrm{S}}$.

In our experiments, phenotype AlbA showed the fastest electrophoretic mobility bands and AlbB showed the slowest mobility in the River buffaloes. Three phenotypes: AlbA, AlbX, and AlbAX were also found in the Swamp buffaloes, and the AlbX showed intermediate mobility between the $\mathrm{A}$ and $\mathrm{B}$ bands. Five phenotypes: (AlbAB, AX, $\mathrm{B}, \mathrm{BX}, \mathrm{X}$ ) were found in their crossbreds. The nomenclature of the alleles of $\mathrm{Alb}^{\mathrm{A}}$, $\mathrm{Alb}^{\mathrm{B}}$, and $\mathrm{Alb}^{\mathrm{X}}$ in our previous reports ${ }^{3), 4)}$ were $\mathrm{Alb}^{3}$,

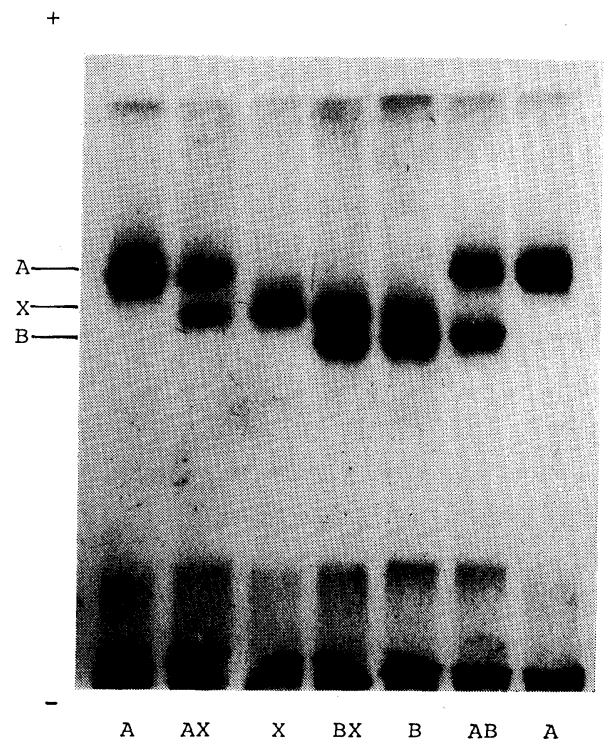

Fig. 1. Electrophoretic variations of serum albumin in the Swamp, River, and their crossbred. 


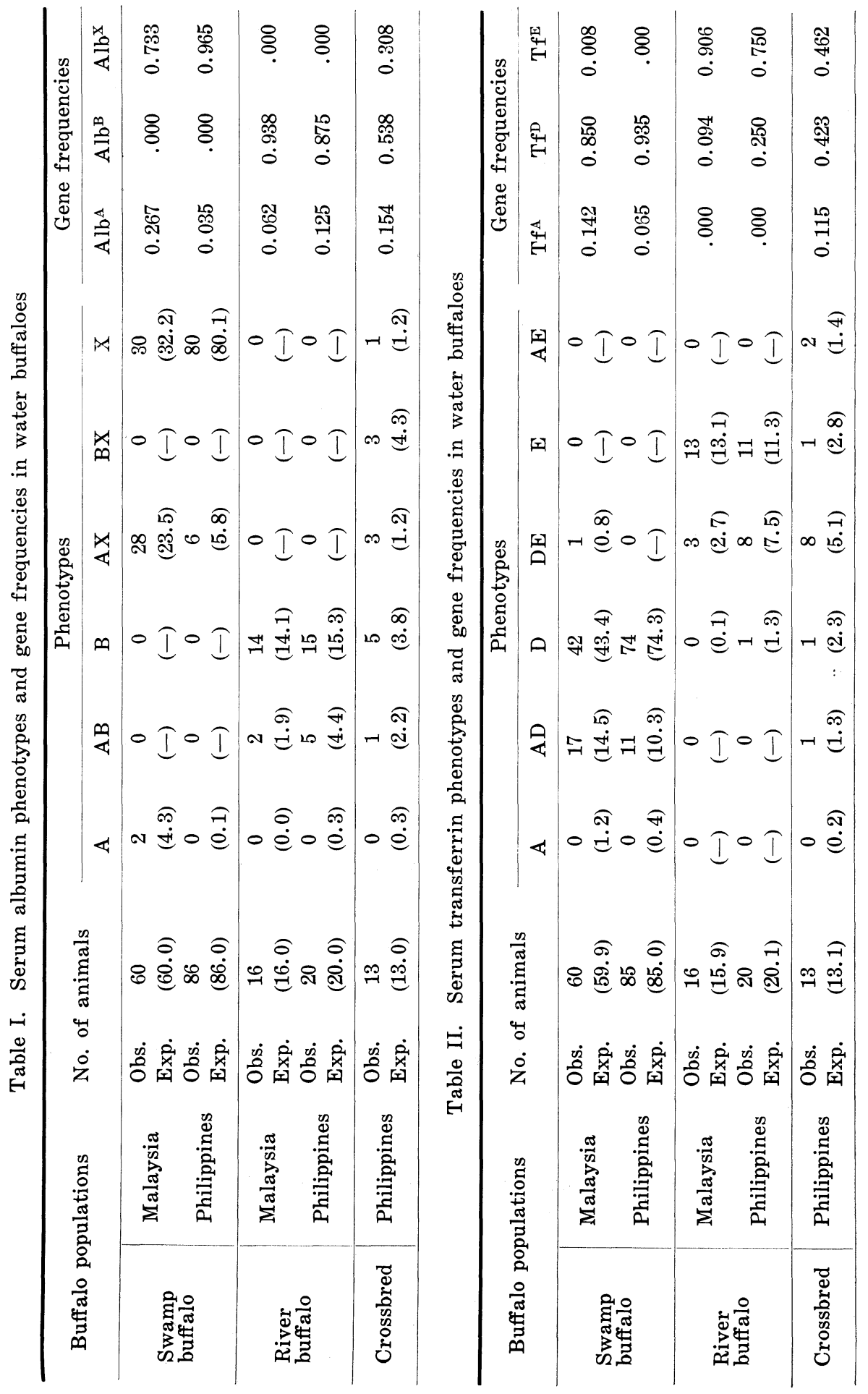


$\mathrm{Alb}^{2}$, and $\mathrm{Alb}^{1}$.

These results showed that the $\mathrm{Alb}^{\mathrm{B}}$ allele existed only in the River buffalo populations with high gene frequencies: 0.938 and 0.875 in Malaysia and the Philippines. In contrast, the Swamp buffalo populations had no $\mathrm{Alb}^{\mathrm{B}}$ gene, and the $\mathrm{Alb}^{\mathrm{X}}$ allele existed only in the Swamp buffalo populations with high gene frequencies (0.733 and 0.965 ). Nor did the River buffalo populations have $\mathrm{Alb}^{\mathrm{x}}$ gene. The $\mathrm{Alb}^{\mathrm{A}}$ was recognized as the common allele in both types of buffalo populations with low gene frequencies $(0.035-0.267)$.

The transferrin phenotypes are shown in Fig. 2. Also, the observed and expected numbers and gene frequencies in the Swamp, River, and crossbred buffalo populations are shown in Table II.

Loypetjra ${ }^{10)}$ and Abe et al. ${ }^{1)}$ reported three phenotypes: TfA, $\mathrm{AD}$, and $\mathrm{D}$ which showed a little faster mobility compared with the bands of cattle, in the Swamp buffaloes of Thailand and Taiwan. They suggested that these transferrin types were determined by codominant autosomal alleles, $\mathrm{Tf}^{\mathrm{A}}$ and $\mathrm{Tf}^{\mathrm{D}}$. Our results similarly showed $\mathrm{TfAD}$ and TfD in all of the Swamp buffaloes except one animal in Malaysia.

On the other hand, in the River buffaloes three phenotypes: TfD, DE, and E showing a little faster mobility compared with the band of cattle were found. Furthermore, five phenotypes (TfAD, AE, D, $\mathrm{DE}, \mathrm{E})$ were found in their crossbreds. The same results for the

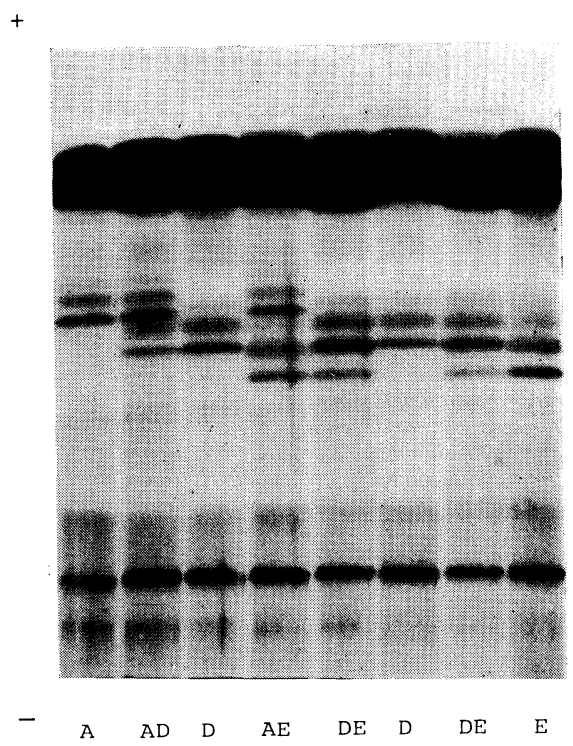

Fig. 2. Electrophoretic variations of serum transferrin in the Swamp, River, and their crossbred. The phenotype TfA has been found in Thailand. ${ }^{2}$ 
River buffaloes were obtained in Bulgarian, ${ }^{12}$ Italian, ${ }^{14)}$ and Romanian $^{7}$ water buffaloes. Makaveyev ${ }^{12}$ ) suggested that the three transferrin phenotypes of Thailand water buffaloes were probably not identical with those of the Bulgarian and Indian buffaloes.

Our experiments established that the TfD which was the most common Tf band of the Swamp buffaloes showed the same mobility with the rare band of the River buffaloes. Otherwise, the mobility of TfE, which was the rare Tf band of the Swamp buffaloes, coincided with that of the most common band of the River buffaloes. Also, the $\mathrm{Tf}^{\mathrm{A}}$ gene existed only in the Swamp buffalo populations; 0.142 and 0.065 in Malaysia and the Philippines. There were very few or no $\mathrm{Tf}^{\mathrm{E}}$ genes in the Swamp buffaloes $(0.008$ and 0.000$)$, whereas the $\mathrm{Tf}^{\mathrm{E}}$ gene was more common in the River buffaloes $(0.906$ and 0.750$)$. The River buffalo had no $\mathrm{Tf}^{\mathrm{A}}$ genes, but their crossbred had both genes, $\mathrm{Tf}^{\mathrm{A}}$ and $\mathrm{Tf}^{\mathrm{E}}(0.115$ and 0.462$)$.

If all of the River buffaloes have these genetic characteristics the distinct genetic differences are indicated between two different types of water buffaloes, not only in the chromosome numbers but also in the blood protein variations. The present studies strongly suggest that the albumin and the transferrin loci can be used as important factors to differentiate the Swamp and River buffaloes as well as their crossbred.

Summary. Alb and Tf variations in Swamp, River and their crossbred buffaloes in Malaysia and the Philippines were analyzed by starch-gel electrophoresis. Three Alb phenotypes (AlbA, AX, X) were found in the Swamp, two phenotypes (AlbA, AB) in the River, and five phenotypes ( $\mathrm{AlbAB}, \mathrm{B}, \mathrm{AX}, \mathrm{BX}, \mathrm{X}$ ) in the crossbred buffalo populations. The $\mathrm{Alb}^{\mathrm{B}}$ gene existed only in the River buffaloes, whereas the $\mathrm{Alb}^{\mathrm{X}}$ gene existed only in the Swamp buffaloes with high gene frequencies. Their crossbreds had both genes. Also, the $\mathrm{Alb}^{\mathrm{A}}$ gene was observed in both types of the buffaloes.

All of the Swamp buffaloes except one animal in Malaysia showed two Tf phenotypes (TfAD, D). The River buffaloes had three phenotypes: TfD, DE, E whereas the crossbred had five: TfAD, AE, D, $\mathrm{DE}, \mathrm{E}$. There was no $\mathrm{Tf}^{\mathrm{A}}$ gene in the River buffaloes, and very few or no $\mathrm{Tf}^{\mathrm{E}}$ gene in the Swamp buffaloes. The most common gene was $\mathrm{Tf}^{\mathrm{D}}$ in the Swamp buffaloes $(0.850-0.935)$, and $\mathrm{Tf}^{\mathrm{E}}$ in the River buffaloes (0.750-0.906). Their crossbred had both $\mathrm{Tf}^{\mathrm{A}}$ and $\mathrm{Tf}^{\mathrm{E}}$ genes. Therefore, the distinct genetic differences were indicated between the Swamp and River buffaloes.

Acknowledgements. The authors express their hearty thanks to Dr. T. I. Azmi and Dr. M. Hilmi of Faculty of Veterinary Medicine and Animal Science, University of Agriculture Malaysia, Professor 
S. H. Escudero III and Dr. Masangkay of College of Veterinary Medicine, University of the Philippines for their kind cooperation, and to the Central Luzon State University for providing the River buffalo samples. They are also deeply indebted to Dr. S. Iseki for his valuable advices. The research was carried out as a part of the project of the Society for Researches on Native Livestock, Japan, and supported in part by the Project research (S. 54-A-6) from Tokyo University of Agriculture.

\section{References}

1) Abe, T., Oishi, T., and Suzuki, S.: Hemoglobin, transferrin, and albumin variants in Formosan water buffalo. Proc. Japan Acad., 45, 767-771 (1969).

2) Amano, T.: Blood groups and serum protein polymorphisms in Thai water buffalo. Rep. Soc. Res. Native Livestock, 6, 87-91, 163-164, 179-180 (1974).

3) - Coat color variation and blood protein polymorphisms of the water buffaloes in the Philippines. Rep. Soc. Res. Native Livestock, 8, 40-45, 116, 125-126 (1978).

4) Amano, T., Namikawa, T., Azmi, T. I., and Hilmi, M.: Gene constitution of water buffaloes in Malaysia. Rep. Soc. Res. Native Livestock, 7, 96102, 131-132, 151-152 (1976).

5) Fischer, H., and Ulbrich, F.: Chromosomes of the Murrah buffalo and its crossbreds with the Asiatic Swamp buffalo (Bubalus bubalis). Z. Tierzücht. Züchtbiol., 84, 110-114 (1968).

6) Gahne, B.: Inherited variations in the post-albumins of cattle serum. Hereditas, 50, 126-135 (1963).

7) Granciu, I., Duicǎ, S., Cureu, I., and Milovan, E.: Blood group and biochemical polymorphism studies in Bos bubalus. Anim. Blood Grps biochem. Genet., 4, 11-14 (1973).

8) Khanna, N. D., and Braend, M.: Haemoglobin and albumin polymorphisms in Indian water buffaloes. Acta vet. Scand., 9, 316-327 (1968).

9) Kristjansson, F. K.: Genetic control of two pre-albumins in pigs. Genetics, 48, 1059-1063 (1963).

10) Loypetjra, P.: Blood haemoglobin and serum albumin types of Thailand water buffaloes (1962). (Referenced from Rendel, J., The husbandry and health of the domestic buffalo, pp. 82-87. FAO (ed. Cocrill, W. R.), Rome, 993 pp., 1974).

11) Macgregor, R.: The domestic buffalo (1939). (Referenced from Mason, I. L., The hasbandry and health of the domestic buffalo, pp.1-47. FAO (ed. Cockrill, W. R.), Rome, 993 pp., 1974.)

12) Makaveyev, T.: Albumin, transferrin, serum amylase and blood groups in Bulgarian water buffalo. Proc. XIth Eur. Conf. Anim. Blood Grps biochem. Polymorphisms (Warsaw, 1968), pp. 235-238 (1970).

13) Mason, I. L.: The husbandry and health of the domestic buffalo, FAO (ed. Cockrill, W. R.), Rome, pp. 1-47 (1974).

14) Masina, P., Iannelli, D., and Bettini, T. M.: Serum albumin and transferrin variants in Italian water buffalo (Bos bubalis L.). Experientia, 27, 587589 (1971). 